\title{
Cervical remodeling during pregnancy and parturition: molecular characterization of the softening phase in mice
}

\author{
Charles P Read, R Ann Word, Monika A Ruscheinsky, Brenda C Timmons and Mala S Mahendroo \\ Department of Obstetrics and Gynecology, The University of Texas Southwestern Medical Center, 5323 Harry Hines \\ Boulevard, Dallas, Texas 75390-9032, USA
}

Correspondence should be addressed to M S Mahendroo; Email: mala.mahendroo@utsouthwestern.edu

\begin{abstract}
Cervical remodeling during pregnancy and parturition is a single progressive process that can be loosely divided into four overlapping phases termed softening, ripening, dilation/labor, and post partum repair. Elucidating the molecular mechanisms that facilitate all phases of cervical remodeling is critical for an understanding of parturition and for identifying processes that are misregulated in preterm labor, a significant cause of perinatal morbidity. In the present study, biomechanical measurements indicate that softening was initiated between gestation days 10 and 12 of mouse pregnancy, and in contrast to cervical ripening on day 18, the softened cervix maintains tissue strength. Although preceded by increased collagen solubility, cervical softening is not characterized by significant increases in cell proliferation, tissue hydration or changes in the distribution of inflammatory cells. Gene expression studies reveal a potentially important role of cervical epithelia during softening and ripening in maintenance of an immunomucosal barrier that protects the stromal compartment during matrix remodeling. Expression of two genes involved in repair and protection of the epithelial permeability barrier in the gut (trefoil factor 1) and skin (serine protease inhibitor Kazal type 5) were increased during softening and/or ripening. Another gene whose function remains to be elucidated, purkinje cell protein 4, declines in expression as remodeling progressed. Collectively, these results indicate that cervical softening during pregnancy is a unique phase of the tissue remodeling process characterized by increased collagen solubility, maintenance of tissue strength, and upregulation of genes involved in mucosal protection.
\end{abstract}

Reproduction (2007) 134 327-340

\section{Introduction}

Premature birth is one of the most significant causes of perinatal morbidity in developed countries, and its incidence over the last decade has been increasing (Branum \& Schoendorf 2002, Ananth et al. 2005). Investigations to define the causes of preterm birth remain a challenge in the obstetrical field as phenotypes of preterm labor and delivery vary extensively. As an example, precocious remodeling of the cervix in the absence of uterine contractions, clinically known as cervical incompetence or insufficiency in humans, is associated with preterm birth (Papiernik et al. 1986).

The cervix is a metabolically active organ in pregnancy composed of extracellular matrix (ECM) components such as collagen, elastin, proteoglycans, and hyaluronan in addition to stromal, epithelial, and smooth muscle cells (Leppert 1995). The cervix is extensively remodeled throughout gestation in order to open sufficiently for safe passage of the fetus during childbirth. Cervical remodeling during pregnancy and parturition is a single continuous process that can be loosely divided into four overlapping phases termed softening (phase 1), ripening (phase 2), dilation/labor (phase 3), and post partum repair (phase 4; Liggins 1978, Word et al. 2007).

In 1895, Hegar first described 'softening' of the lower uterine segment in association with human pregnancy at 4-6 weeks. The Hegar sign refers to the characteristic softening of the uterus in cervix that is evident on physical examination during early pregnancy, and it was customarily used to clinically diagnose pregnancy until the discovery of human chorionic gonadotropin many years later (Hegar 1895). Cervical softening can be defined as a change in the biomechanical properties of the cervix when compared with the nonpregnant cervix and is characterized by a progressive decrease in tissue stiffness without loss of tensile strength (Leppert \& Yu 1994). The ability of the cervix to soften yet remain resistant to forces exerted upon it requires dual mechanisms in which there is an increase in the geometry (size) of the cervix along with maintained 
stiffness of the cervical wall (Drzewiecki et al. 2005). Physiologic softening of the rat cervix was first recognized by Harkness \& Harkness (1959) who noted that distensibility of cervical tissue increased dramatically starting midgestation between days 11 and 12 (Harkness \& Harkness 1959). An increase in the diameter of the cervical canal between gestation days 10 and 12 was used initially as a crude measurement to define cervical softening in the mouse (Leppi 1964). The change in diameter, however, was $<1 \mathrm{~mm}$ and statistical analysis was not performed. Changes in tissue compliance during softening are proposed to be facilitated by changes in the composition or structure of the ECM in humans and rats (Danforth et al. 1974, Liggins 1978, Leppert 1995). This is supported by the fact that cervical incompetence is increased in women with inherited defects in collagen and elastin synthesis or assembly (e.g. Ehlers-Danlos and Marfan syndromes; Paternoster et al. 1998, Rahman et al. 2003). In addition, mice deficient in the ECM protein, thrombospondin 2, have altered collagen fibril morphology and premature cervical softening (Kokenyesi et al. 2004).

Cervical softening begins early in mammalian pregnancies and overlaps at the end of gestation in a second phase of matrix remodeling commonly referred to as cervical ripening. While the endocrine events that herald this stage differ from species to species, the series of events that bring about ripening are very similar. Cervical ripening has been studied much more extensively than the process of cervical softening. Ripening is characterized by an increase in hyaluronan content, loosening of the collagen matrix, increased collagen solubility (Hillier \& Wallis 1982, Granstrom et al. 1989), changes in the distribution of inflammatory cells, increased tissue growth and hydration, and loss of tensile strength (Uldbjerg et al. 1983, Buhimschi et al. 2004, Straach et al. 2005, Timmons \& Mahendroo 2006). In contrast to cervical ripening, the biochemical and molecular changes that occur during cervical softening are not well-defined. We propose that processes regulating softening events may differ from cervical ripening and are crucial to our understanding of cervical remodeling for successful delivery of young. The objective of the current series of experiments is to understand the midgestation cervical softening process in mice and to identify genes that may be integral to one or all stages of the cervical remodeling process.

\section{Materials and Methods \\ Mice}

Animals were housed under a $12 \mathrm{~L}: 12 \mathrm{D}$ photoperiod (lights-on, $0600-1800 \mathrm{~h}$ ) at $22^{\circ} \mathrm{C}$. Mice used in the present studies were of mixed strain $(\mathrm{C} 57 \mathrm{BL} / 6 \times$ 129SvEv). The C57BL/6×129SvEv mice were generated and maintained as a breeder colony at the University of
Texas Southwestern Medical Center (Dallas, TX, USA). In general, mice in these studies were 3-6 months old and nulliparous. Female mice were housed overnight with males and checked at midday for vaginal plugs in order to obtain accurately timed pregnant mice. The day of plug formation was counted as day 0 , and birth occurred in the early morning hours of day 19 . Cervices collected before noon on the day of birth were estimated to be $10 \mathrm{~h}$ post partum and those collected before noon on the day after birth were estimated to be $24 \mathrm{~h}$ post partum. All studies were conducted in accordance with the standards of humane animal care as described in the NIH Guide for the Care and Use of Laboratory Animals. The research protocols were approved by the institutional animal care and research advisory committee.

\section{Cervical tissue collection}

Animals were given anesthesia with $1.25 \%$ tribromoethanol $(25 \mu \mathrm{l} / \mathrm{g}$ of body weight injected intraperitoneally). After euthanasia by cervical dislocation, the uterine horns, cervix, and vagina were removed. Using a dissecting microscope, the cervix was isolated by transection at the utero-cervical junction (caudal to the uterine bifurcation) and removal of all vaginal tissue from cervical tissue specimens. All specimens for RNA extraction were immediately snap frozen in liquid nitrogen.

\section{Tissue biomechanics}

Tensile distensibility and maximum stretch of isolated cervical tissues was conducted according to a method developed by Harkness \& Harkness (1959) and adapted in our laboratory. The excised cervix was mounted by means of two pins inserted through the cervical canal. One pin was attached to a calibrated mechanical drive and the other pin to a force transducer. Tissues were incubated in a water-jacketed bath containing physiologic saline solution $(\mathrm{NaCl}(120.5 \mathrm{mM}), \mathrm{KCl}(4.8 \mathrm{mM})$, $\mathrm{MgCl}_{2}(1.2 \mathrm{mM}), \mathrm{CaCl}_{2}(1.6 \mathrm{mM}), \mathrm{NaH}_{2} \mathrm{PO}_{4}(1.2 \mathrm{mM})$, $\mathrm{NaHCO}_{3}(20.4 \mathrm{mM})$, dextrose $(10 \mathrm{mM})$, and pyruvate $(1.0 \mathrm{mM}), \mathrm{pH} 7.4$ at $37^{\circ} \mathrm{C}$ ) bubbled with $95 \% \mathrm{O}_{2} / 5 \%$ $\mathrm{CO}_{2}$. Baseline cervical dilatation (i.e. resting diameter of cervical os) was quantified by determining the difference in cervical diameter at 0 (pins juxtaposed with no tension) and the inner cervical diameter at the initiation of tension as the pins were separated. Thereafter, the inner diameter of the cervix was increased isometrically in $0.5 \mathrm{~mm}$ increments at 2-min intervals. The amount of force required to distend the cervix and the tension exerted by the stretched tissue were recorded. The diameter was increased until either forces exerted by the tissue reached a plateau or the tissue tore. Force was plotted as a function of cervical diameter. Crosssectional area and stress (force/cross-sectional area) 
were calculated. The slope of the linear portion of the force-strain curve was computed as an index of tissue stiffness and elasticity (Young's modulus).

\section{Water content}

Cervix tissue was weighed immediately after tissue collection (wet weight) and again after freeze-drying overnight (dry weight). Water content was determined by the ratio of the difference between the wet and dry cervical weights to the dry cervical weight (wet weightdry weight)/wet weight (Anderson et al. 2006).

\section{Collagen solubility}

Dry cervical samples were homogenized and incubated in $0.5 \mathrm{ml}$ of $0.5 \mathrm{M}$ acetic acid, $1 \mathrm{mg} / \mathrm{ml}$ pepsin (Sigma, catalog no. P7012-1G) at $4{ }^{\circ} \mathrm{C}$ for $24 \mathrm{~h}$ with gentle agitation. Samples were spun at 12000 r.p.m. (13 400 g) and supernatant containing soluble collagen was separated from the insoluble pellet. Soluble collagen was hydrolyzed by the addition of an equal volume of $12 \mathrm{M} \mathrm{HCl}$ for a final concentration of $6 \mathrm{M} \mathrm{HCl}$. The insoluble collagen was hydrolyzed by the addition of $6 \mathrm{M} \mathrm{HCl}$. Both fractions were incubated at $100^{\circ} \mathrm{C}$ for $20 \mathrm{~h}$. Samples were allowed to cool uncapped and incubated at $100{ }^{\circ} \mathrm{C}$ until $\mathrm{HCl}$ was evaporated. The dried hydrolysates were dissolved in $250 \mu \mathrm{l}$ of water and the hydroxyproline concentration in each fraction measured by a colorimetric method according to methods as described (Stegemann \& Stalder 1967). Briefly, $20 \mu \mathrm{l}$ sample or standard was diluted in $500 \mu \mathrm{l}$ water. Two hundred and fifty microliters of chloramine- $\mathrm{T}$ solution (1.41 g chloramine- $\mathrm{T}$ (Sigma), $10 \mathrm{ml} \mathrm{H} \mathrm{H}_{2} \mathrm{O}, 10 \mathrm{ml} n$ propanol, and $80 \mathrm{ml} \mathrm{OH}$-pro buffer) were added to each tube and incubated at RT for $20 \mathrm{~min}$. (OH-pro buffer: $50 \mathrm{~g}$ citric acid $1 \mathrm{H}_{2} \mathrm{O}, 12 \mathrm{ml}$ acetic acid, $120 \mathrm{~g}$ sodium acetate $3 \mathrm{H}_{2} \mathrm{O}, 24 \mathrm{~g} \mathrm{NaOH} . \mathrm{H}_{2} \mathrm{O}$ is added to bring volume up to $1200 \mathrm{ml}$ with water. $\mathrm{pH}$ to 6.0 with $6 \mathrm{~N} \mathrm{NaOH}$ and then add $300 \mathrm{ml} n$-propanol). Two hundred and fifty microliters of aldehyde/perchloric acid solution (1 g p-dimethyl-amino-benzaldehyde (JT Baker, Phillipsburg, NJ, USA), $4 \mathrm{ml} n$-propanol, and $1.73 \mathrm{ml}$ $70 \%$ perchloric acid) was added to all samples and standards, vortexed, and incubated at $60{ }^{\circ} \mathrm{C}$ for $15 \mathrm{~min}$. Two hundred and fifty microliters of each sample were aliquoted into a 96-well microtiter plate and absorbance was measured at $558 \mathrm{~nm}$ on a Tecan Saffire 2 microplate reader (Tecan, San Jose, CA, USA). A trans-4-hydroxy-Lproline (Sigma catalog no. 56250) standard series (6, $3,2,1,0.5$, and $0.2 \mu \mathrm{g}$ ) and blank (water) were included in the experiment. All measurements were carried out in duplicate, and samples that had an absorbance higher than that of the most concentrated standard were diluted further and measured again. The hydroxyproline concentration in the soluble and insoluble fraction was interpolated from the standard curve and expressed as a percentage of the total $\mathrm{OH}-\mathrm{Pro}$ in the sample. Total $\mathrm{OH}-\mathrm{Pro}$ in the sample was determined by adding $\mathrm{OH}$-Pro in soluble and insoluble fractions. The amount of total collagen was calculated by assuming the hydroxyproline content of collagen was $14 \%$ (Horgan et al. 1990). The concentration of collagen was determined by dividing the total collagen $(\mu \mathrm{g})$ by the wet weight (mg) of the tissue. Four to six cervices were measured individually for each time point and data represent an average \pm S.E.M.

\section{Immunohistochemistry}

Freshly excised cervices were embedded in OCT compound (Tissue Tek; Bayer Corp., Elkhart, IN, USA) and frozen immediately in liquid nitrogen. Air-dried tissue sections (thickness, $5 \mu \mathrm{m}$ ) were fixed for $10 \mathrm{~min}$ in acetone. Nonspecific binding was blocked using 1.5\% normal donkey serum for $20 \mathrm{~min}$. Sections were incubated for $30 \mathrm{~min}$ at $25^{\circ} \mathrm{C}$ with the monoclonal antibody, neutrophil 7/4, a rat anti-mouse neutrophil, and monocyte-specific antibody at a working dilution of $0.01 \mathrm{mg} / \mathrm{ml}$ (Serotec, Raleigh, NC, USA) or rat anti-mouse BM8, a macrophage-specific antibody ( $1: 800$ of a $0.5 \mu \mathrm{g} / \mathrm{ml}$ stock; BACEM Biosciences Inc., King of Prussia, PA, USA). Neutrophil 7/4 recognizes myeloid lineage leukocytes, including neutrophils and monocytes, but not macrophages (Henderson etal. 2003, Taylor etal. 2003). BM8 is a pan-macrophage marker that recognizes the $F 4 / 80$ antigen found on cell membranes and the cytosol of mononuclear phagocytes (Mackler et al. 1999). Biotinylated donkey anti-rat (1:200; Jackson Laboratories, Westgrove, PA, USA) and alkaline phosphatase-conjugated avidin-biotin complex (Vector Laboratories, Burlingame, CA, USA) were applied in sequence followed with Vector Red substrate (Vector Laboratories). Tissues were counterstained in hematoxylin for $10 \mathrm{~s}$. The primary antibody was replaced with rat IgG2a (Caltag Laboratories, Burlingame, CA, USA) as a negative control. Three animals were tested for each time point. Nonpregnant cervices were collected during metestrus.

\section{RNA isolation and quantitative real-time PCR}

Total RNA was extracted from frozen tissue using RNA Stat 60 (Tel-test B, Friendswood, TX, USA). Total RNA was treated with DNase I (DNA free; Ambion, Austin, TX, USA) to remove any genomic DNA contamination. cDNA was synthesized using a TaqMan cDNA synthesis kit (Applied Biosystems, Foster City, CA, USA). RT-PCR was performed using SYBR Green and a PRISM 7900HT Sequence Detection System (Applied Biosystems). Aliquots (20 ng) of total cDNA were used for each PCR and were performed in triplicate. Expression of each gene was expressed relative to that of the housekeeping 
gene cyclophilin (Ppib). Relative levels of gene expression were determined by the $\mathrm{ddCt}$ method (Applied Biosystems User Bulletin \#2).

\section{Microarray}

RNA from three separate cervical samples were obtained on days 10 and 12 of gestation and subjected to microarray experiments. Gene Spring 5.0 (Silicon Genetics, Redwood City, CA, USA) software was used in data analysis and statistical calculations. Affymetrix mouse expression chip 4302.0 data were exported to the gene analysis software. Per chip normalization to the 50th percentile expression level and per gene normalization to the median expression of all samples was performed. Only probes with two out of three samples scored as either present or marginal were used in the data analysis. Probe sets with average expression of 40 or less in both experimental and control groups were excluded. Fold change expression was calculated as the median expression of day 12 over the expression of day 10 in mouse cervix tissue. Annotations for the probe sets were derived from the Affymetrix web site (http://www. affymetrix.com/) and were updated with publicly accessible databases: National Center for Biotechnology Information (http://www.ncbi.nih.gov/), Information Hyperlinked over Proteins (http://www.ihop-net.org/ UniPub/iHOP/), and Swiss Prot (http://www.ebi.ac.uk/ swissprot/) to verify gene identity and update annotations from current literature references. After generating a comprehensive gene list, the function and ontology of each gene were examined and then scored to determine possible relevance to cervical remodeling. From this list, a number of genes were chosen for further validation and analysis.

\section{Statistical tests}

Means of data were compared with Student's $t$-test where appropriate. Two-tailed $P$-value $\leq 0.05$ was considered statistically significant. For multiple comparisons, a Kruskal-Wallis one way ANOVA on ranks was performed followed by the Dunnett or Tukey method. For the microarray analysis, a gene was considered significant if one of two conditions were satisfied: first, if there was a two-fold change in mean expression of the gene from days 10 to 12 of gestation as calculated by Gene Spring, or second, if there was a statistically significant change in expression as determined by parametric testing adjusted for multiple comparisons. These two methods were combined to create a comprehensive and inclusive gene list. Statistical significance was defined in this context using a Benjamini and Hochberg false discovery rate (FDR) of $<40 \%$. An FDR $<40 \%$ has been considered appropriate for exploratory research and gene discovery
(Welle et al. 2002, Reiner et al. 2003). Real-time PCR was used to confirm the differential expression of genes found to be significant by the microarray analysis to reduce the possibility of finding false positives from the less stringent microarray analysis.

\section{Results}

\section{Biomechanical characterization of cervical softening}

To better define the time point at which cervical softening begins in the mouse when compared with earlier studies (Leppi 1964), biomechanical studies were carried out in cervices from nonpregnant and timemated pregnant mice on gestation days 10, 11, 12, and 18 using methods that have been described previously (Word et al. 2005). Data shown for gestation day 18 is previously published and is shown in Fig. 1 for comparison to days 10-12 (Word et al. 2005). Cervical stiffness on day 10 (day 10) was not statistically significant from that of nonpregnant animals. Cervical tissues from nonpregnant animals and pregnant mice on day 10 were not distensible as the cervix could not be stretched to more than $3.5 \mathrm{~mm}$ before failure (Fig. 1A and $\mathrm{B})$. By day 12 , cervical stiffness $(\mathrm{g} / \mathrm{mm})$ decreased from $20.2 \pm 2.6 \mathrm{~g} / \mathrm{mm}$ in nonpregnant animals to $6.2 \pm$ $0.9 \mathrm{~g} / \mathrm{mm}(P \leq 0.001$, Fig. $1 \mathrm{~A})$, and cervical distensibility increased from $3.2 \pm 0.2 \mathrm{~mm}$ in nonpregnant animals to $6.9 \pm 0.5 \mathrm{~mm}$ on day $12(P \leq 0.001)$. Cervical stiffness declined further from days 12 to $18(P<0.001)$, and distensibility also increased dramatically from days 12 to $18(P<0.001$; Fig. $1 \mathrm{~A}$ and B). Despite decreased tissue stiffness and increased cervical distensibility on day 12 , the maximal load before failure was similar in nonpregnant and pregnant animals on days 10 and 12 $\left(99 \pm 19 \mathrm{mN} / \mathrm{mm}^{2}\right.$ when compared with $129 \pm$ $17 \mathrm{mN} / \mathrm{mm}^{2}, p=\mathrm{NS}$, Tukey) suggesting that collagen integrity is maintained (Table 1). In contrast, the maximal load before failure decreased on late day 18 to $41 \pm$ $8 \mathrm{mN} / \mathrm{mm}^{2}$ (when compared with day 12, $P<0.05$, Tukey), suggesting that, in contrast to the softened cervix, the ripened cervix lacks cervical strength (Table 1). Collectively, these data indicate that, in the mouse, a significant change in biomechanical properties of the cervix (i.e. cervical softening) occurs by gestation day 12 , and that certain biomechanical changes during the ripening phase are distinct from those during cervical softening.

\section{Physiological properties of the cervix during pregnancy: hydration and collagen solubility}

Having verified the time point at which softening begins, studies were undertaken to identify physiological changes that may facilitate this process. To determine if tissue growth or changes in tissue hydration occur during softening, cervical wet weight, dry weight, and water 


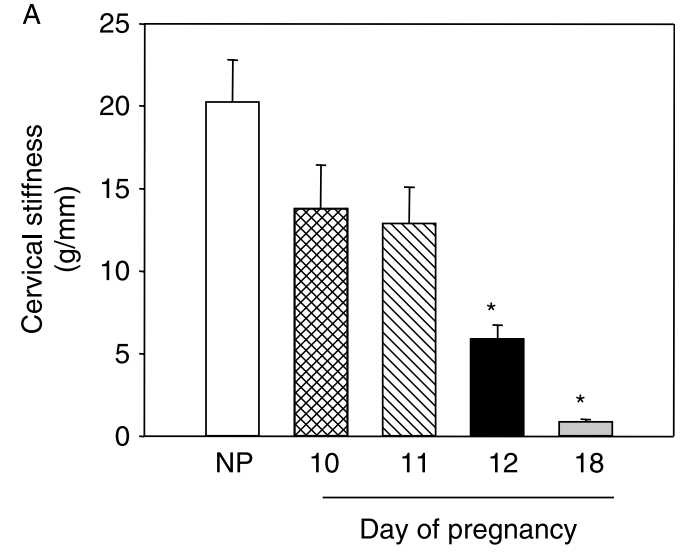

B

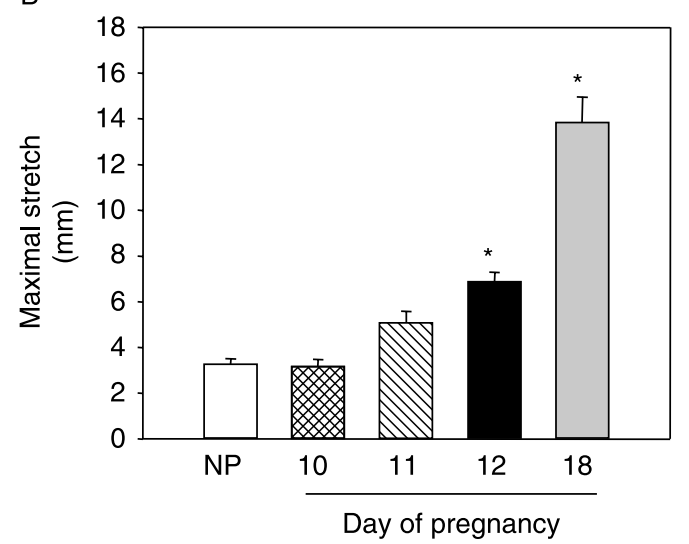

Figure 1 Biomechanical properties of the mouse cervix during early pregnancy. (A) Tissue stiffness was determined from the slope of the stress-strain relationship in cervices from nonpregnant (NP, open bar, $n=8$ ) and pregnant mice on gestation days 10 (hatched bar, $n=6$ ), 11 (diagonal lines, $n=7$ ), 12 (solid bar, $n=8$ ), and 18 and 19 (gray bar, $n=11$ ). ${ }^{*} P \leq 0.001$ when compared with NP. (B) Cervices from nonpregnant (NP) and pregnant mice on gestation days $10,11,12$, and 18 and 19 were distended in $0.5 \mathrm{~mm}$ increments every 2 min until failure. Data are expressed as maximal distension in $\mathrm{mm}$ and represent mean \pm S.E.M. of $6-11$ cervices per time point. ${ }^{*} P \leq 0.001$ when compared with nonpregnant.

content were measured in multiple cervices from nonpregnant and pregnant animals at selected intervals throughout gestation (Fig. 2). The wet and dry cervical weights were similar in nonpregnant and pregnant animals in early gestation (i.e. days 10-12). This suggests that increases in cervical tissue mass either through increased synthesis of ECM, cell proliferation, or tissue hydration were not significant during early gestation. Even though cervical dry weight increased 1.9-fold from early pregnancy to shortly before birth on day 18.75 $(P<0.001)$, the increase in cervical wet weight was 2.5 fold (from $9.1 \pm 0.4$ to $22.2 \pm 1.3 \mathrm{mg}, P<0.001$ ) suggesting that increases in cervical weight during late gestation are due to both increased protein synthesis as well as a modest increase in water content. The finding that tissue hydration increased from $74.7 \pm 5.4 \%$ (days $10-12$ ) to $78.6 \pm 1.8 \%$ on day 18.75 is in agreement with
Table 1 Maximal load before tissue failure for non-pregnant (NP) and gestational age days 10 (day 10), 12 (day 12), and 18 (day 18) mouse cervix ( $n=6-8$ per time point).

\begin{tabular}{lcc}
\hline Stage & Average & S.E.M. \\
\hline Non-pregnancy & $168.0^{*}$ & 25.1 \\
Pregnancy & & \\
Day 10 & 99.0 & 19.0 \\
Day 12 & $128.7^{+}$ & 17.2 \\
Day 18 & $41.0^{*}{ }^{+}$ & 7.7 \\
\hline
\end{tabular}

*Indicates $P<0.001$ and ${ }^{+}$refers to $P<0.05$ for comparison.

this interpretation and previously reported studies (Rimmer 1973, Anderson et al. 2006).

Changes in the solubility characteristics of collagen depend on the number of covalent cross-links between collagen triple helices which are required for the formation of stable collagen fibrils (Robins et al. 2003). Previous studies in humans confirm increased solubility of collagen in the presence of acetic acid and pepsin during cervical ripening (Granstrom et al. 1989). We sought to determine if the progressive increase in tissue compliance observed during softening and ripening correlates with progressive changes in collagen solubility. Cervices from nonpregnant (early metestrus), gestation days $7,10,12,18$, and 10 or $24 \mathrm{~h}$ post partum were homogenized and extracted in $0.5 \mathrm{M}$ acetic acid containing $1 \mathrm{mg} / \mathrm{ml}$ pepsin for $24 \mathrm{~h}$. The percentage of collagen in the soluble and insoluble fraction was determined by quantitative measurement of hydroxyproline (Stegemann \& Stalder 1967). Forty-three percent of collagen were soluble in pepsin in nonpregnant mice (Fig. 3A). As early as day 7 the solubility increased to $61 \%$ (nonpregnant versus day $7, P=0.03$ ) and reached a peak of $74 \%$ at gestation day 12 (day 7 vs day $12, p=N S$ ) with no further increases in solubility during cervical ripening on gestation day 18 (73\%) (day 12 vs day 18, $p=N S)$. The percentage of collagen in the soluble fraction rapidly declined in the post partum (PP) period and within $24 \mathrm{~h}$ after birth is similar to nonpregnant mice (day 18 vs $1 \mathrm{dPP}, P<0.01$ ). This data suggest that an increase in soluble collagen accompanies the changes in biomechanical properties of the cervix during softening but the progressive increase in tissue compliance during cervical ripening is not correlated with further increases in collagen solubility. Compared to nonpregnant cervix (metestrus), there were no significant changes in collagen content during pregnancy in contrast to the post partum period when there is a significant increase (Fig. 3B). While there appeared to be a decline in collagen concentration right before parturition when compared with nonpregnant (Fig. 3C), this trend did not reach statistical significance. Collagen concentration was at its maximal on day 7 and significantly declined on days 12,18 , and $10 \mathrm{~h}$ post partum when compared with day $7(P<0.05$, Tukey test). 


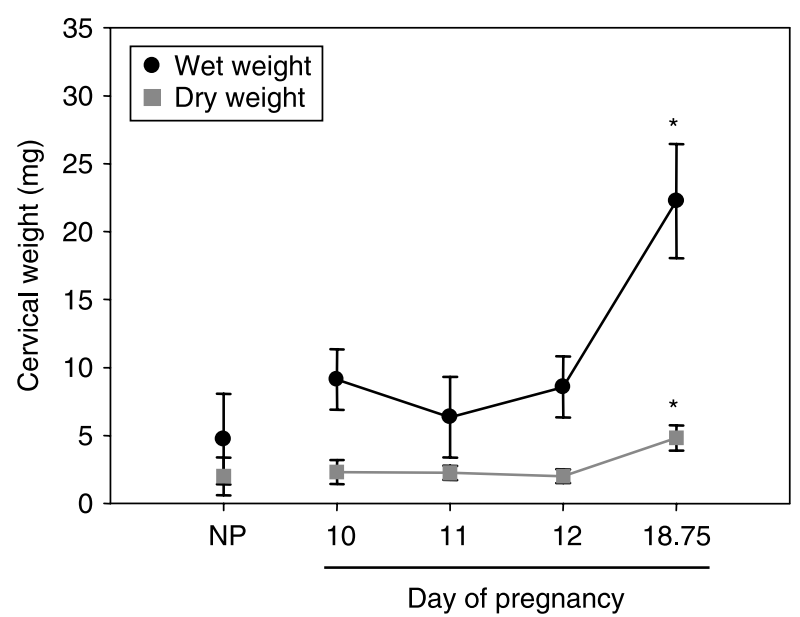

Figure 2 Regulation of cervical weight in pregnant mice during pregnancy. Cervical dry (gray square) and wet (black circle) weights were determined in nonpregnant (NP) and pregnant mice on gestation days $10,11,12$, and 18.75 . Both the mean cervical wet and dry weights were greater just prior to delivery at day 18.75 when compared with cervical tissues from nonpregnant or pregnant mice earlier in gestation $\left({ }^{*} P<0.001\right.$, Dunnett). ( $n=5-11$ cervices at each time point).

\section{Role of inflammatory cells during cervical softening}

To determine if the softening process is accompanied by changes in inflammatory cell distribution, immunohistochemical detection of macrophages, neutrophils, and monocytes was carried out using frozen cervical sections from nonpregnant and pregnant mice at gestation days 10 and 12 with antibodies that detect monocytes and neutrophils (7/4) and macrophages (BM8) as described previously (Mackler et al. 1999, Henderson et al. 2003, Timmons \& Mahendroo 2006). 7/4- (Fig. 4, upper panels) and BM8-positive cells (Fig. 4, lower panels) were observed in both pregnant and nonpregnant sections with 7/4-positive cells predominantly lining the cervical epithelium and BM8-positive cells residing within the stroma near the subepithelial regions. This distribution pattern of immune cells at days 10 and 12 is similar to nonpregnant cervical tissues in metestrus (Fig. 4) and differs significantly to changes in distribution of immune cells observed during ripening (Timmons \& Mahendroo 2006). This suggests that although a significant number of inflammatory cells are present in the cervix at this time in pregnancy, there appears to be little change in the distribution of neutrophils, monocytes or macrophages within the cervix from days 10 to 12 during cervical softening.

\section{Differential expression of genes in the cervix during cervical softening: results of microarray analysis}

Further studies were carried out to identify genes that may be transcriptionally regulated during cervical softening. Total RNA from three cervices each at gestation days 10 and 12 was hybridized to six Affymetrix microarray chips.
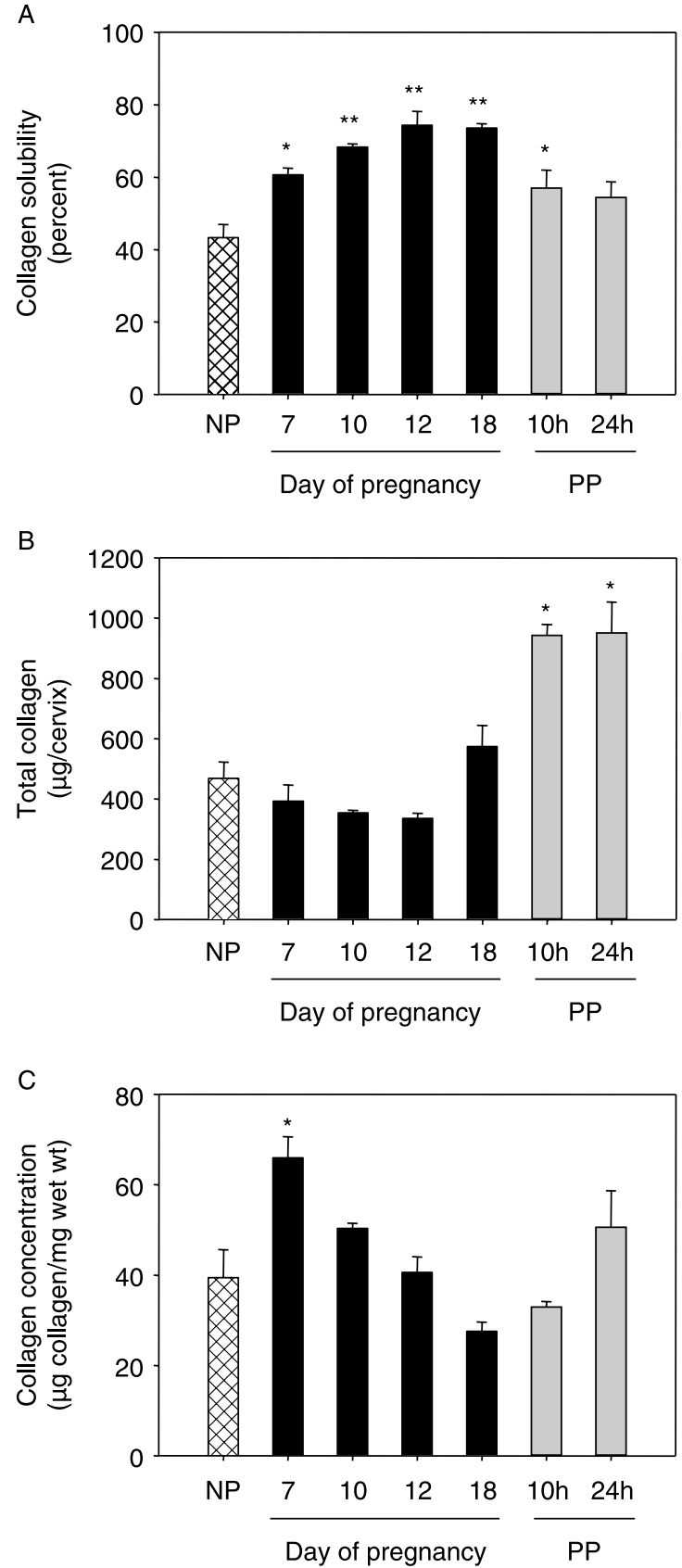

Figure 3 Collagen solubility, total collagen, and collagen concentration in cervical tissues from nonpregnant (NP), pregnant (days 7, 10, 12, and 18) and post partum (PP) mice. Percentage of solubilized collagen was determined in nonpregnant metestrus (hatched bar), pregnant (black bars), and post partum (grey bars) (A). Total amount of collagen in the cervix and concentration of collagen normalized to cervical wet weight are shown in (B and $\mathrm{C}$ ) respectively. ${ }^{*} P<0.05$; ${ }^{* *} P<0.001$, ANOVA Dunn test comparison with NP ( $n=4-6$ cervices at each time point).

Of 45037 sequence tags on the array, expression of 21544 genes was detectable in cervical tissue. One hundred and forty-six genes were significantly upregulated and 96 were downregulated in cervical tissues on day 12 when compared with day $10\left(\chi^{2}, P=0.001\right)$. 
NP
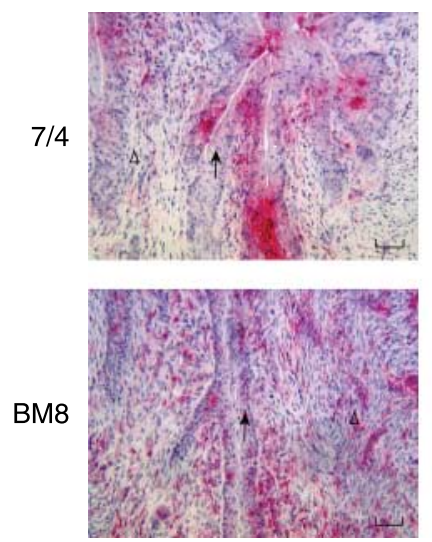

d10
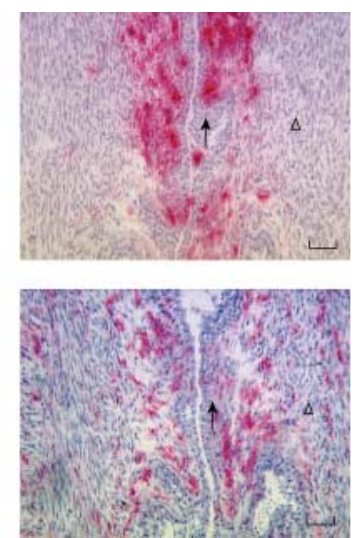

d12
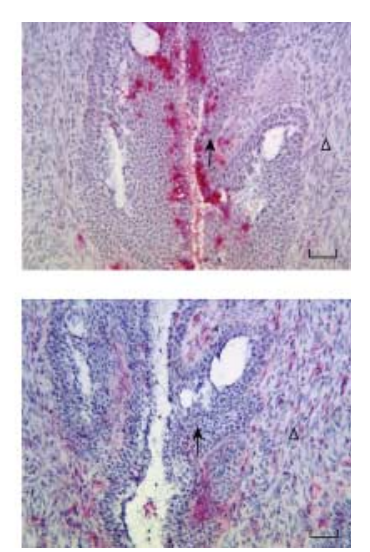

Figure 4 Immunolocalization of leukocytes (neutrophils and monocytes) and macrophages in cervical tissues from nonpregnant (NP) and pregnant mice on gestation days 10 and 12. Tissue sections were oriented in the sagittal plane through the cervical os. The cervical lumen lined by epithelial cells is indicated by arrows and cervical stroma by open arrowheads. Immunohistochemistry was conducted using MAB 7/4 (upper panels) and BM8 (lower panels). Positive immunoreactivity is indicated by red staining. 7/4-positive cells (leukocytes and monocytes) were predominantly localized in the epithelium, whereas macrophages were primarily localized in the subepithelial and stromal compartments of the cervix. Sections are representative of three cervices from each gestation day. Bar represents $20 \mu \mathrm{m}$.

The first criterion for differential expression of genes during cervical softening (mean difference in expression from days 10 to 12 by $\geq$ two-fold) yielded a gene list with 64 entries and is represented in Table 2 (upregulated genes) and Table 3 (downregulated genes). Using parametric statistical tests adjusting for multiple comparisons generated an additional gene list of 247 entries. This list is available as supplemental material (Supplemental Table 1, which can be viewed online at www.reproduction-online.org/supplemental/). Candidate genes identified in microarray analysis based on a two-fold change (Cxcl5, Mcp7, Pcp4, Spink5, and Tff1; Tables 2 and 3) were more often confirmed by RT-PCR than genes selected based on parametric statistical analysis (Aspn and Sdc2; Supplement).

The function and ontology of genes identified by mean difference in expression (Tables 2 and 3) or statistical tests (Supplemental table) were reviewed to identify those genes with a potential role in cervical softening. Contrary to our hypothesis, relatively few genes encoding ECM proteins were changed in expression between the two time points. Cervical softening was associated with increased expression of genes encoding protease inhibitors (serine protease inhibitor Kazal type 5 (Spink5); serine proteinase inhibitor, clade B, member 5; and serine protease inhibitor, Kunitz type 2), mucosal epithelial cell repair/anti-inflammatory proteins (trefoil factor 1 , chitinase 3 like-1, decay accelerating factor, and platelet-activating factor acetylhydrolase, isoform $1 \mathrm{~b}$, beta 1 subunit), and neutrophil chemoattractants (chemokine C-X-C ligand 5). Of the total gene list, eight genes were selected for further analysis based on their likelihood of contributing to cervical softening.

Two genes, asporin (Aspn) and syndecan 2 ( $S d c 2$ ), were selected as they encode ECM proteins that could influence changes in the cervical ECM during softening. Other candidate genes included chemokine ligand 5 (CxCl5, a neutrophil chemoattractant expressed by epithelial cells), mast cell protease 7 (Mcp7, a serine protease expressed in mast cells), trefoil factor 1 (Tff1, a secreted protein involved in repair and protection of gastrointestinal mucosal epithelia), purkinje cell protein 4 (Pcp4, a neuronal specific calmodulin regulatory protein that inhibits apoptosis), serine proteinase inhibitor lympho-epithelial Kazal-type inhibitor (Spink5, a protease inhibitor that prevents degradation of proteins required for maintenance of an intact epithelial barrier), and decay accelerating factor (Daf1, a protein that suppresses inflammatory responses via inhibition of activation of the complement cascade; Lin et al. 2001, Kanamori et al. 2003, Singh et al. 2004, Yang et al. 2004, Funaba et al. 2006, Masui et al. 2006).

\section{Regulation of gene expression in the cervix during pregnancy and parturition}

Relative mRNA levels of selected genes were determined in cervical tissues from mice on gestation days 10 and 12. Asporin (Aspn), syndecan 2 (Sdc2), mast cell protease 7 (Mcp 7), and decay accelerating factor 1 (Daf1) were found to be differentially expressed on the microarray, but further analysis with RT-PCR did not substantiate these differences (Fig. 5). Four genes with confirmed changes are indicated (Fig. 5). The analysis of relative mRNA levels of these genes was subsequently expanded to include cervical samples that were obtained throughout gestation (from day 8 through day 1 post partum) using RT-PCR (Fig. 6). Chemokine C-X-C ligand 5 ( $\mathrm{CxCl} 5)$ encodes a neutrophil chemoattractant and was found to be upregulated on day 12 (Fig. 5). 
Table 2 Upregulated genes on day 12 when compared with day 10 of gestation in mouse cervical tissue.

\begin{tabular}{|c|c|c|c|c|}
\hline Entrez gene ID & Gene title & Fold change & S.D. ${ }^{*}$ & $P$ value \\
\hline \multicolumn{5}{|c|}{ Transport functions } \\
\hline 12870 & Ceruloplasmin & 2.38 & 1.73 & 0.092 \\
\hline 56774 & Solute carrier family 6 (neurotransmitter transporter), member 14 & 2.21 & 2.95 & 0.184 \\
\hline 23844 & Chloride channel calcium activated 3 & 2.19 & 0.89 & 0.027 \\
\hline \multicolumn{5}{|c|}{ Cytoskeletal components } \\
\hline 19240 & Thymosin, beta 10 & 4.59 & 5.13 & 0.132 \\
\hline 16660 & Keratin complex 1 , acidic, gene 1 & 2.68 & & 0.296 \\
\hline 16687 & Keratin complex 2 , basic, gene $6 a$ & 2.33 & 1.67 & 0.211 \\
\hline 18472 & Platelet-activating factor acetylhydrolase, isoform $1 \mathrm{~b}, \beta 1$ subunit & 2.16 & 1.41 & 0.471 \\
\hline \multicolumn{5}{|c|}{ 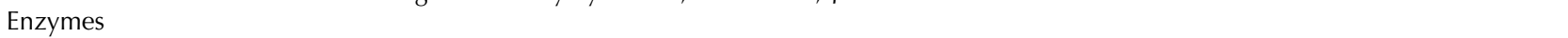 } \\
\hline 241230 & ST8 alpha- $N$-acetyl-neuraminide $\alpha$-2,8-sialyltransferase 6 & 3.02 & 1.89 & 0.126 \\
\hline 14933 & Glycerol kinase & 2.46 & 1.30 & 0.070 \\
\hline 68631 & Crystallin, $\lambda 1$ & 2.21 & & 0.422 \\
\hline 14538 & Glucosaminyl ( $N$-acetyl) transferase 2, I-branching enzyme & 2.08 & 0.89 & 0.316 \\
\hline \multicolumn{5}{|c|}{ Cellular growth and differentiation } \\
\hline 21784 & Trefoil factor 1 & 2.19 & 0.68 & 0.040 \\
\hline 21946 & Peptidoglycan recognition protein 1 & 2.03 & 0.37 & 0.061 \\
\hline \multicolumn{5}{|l|}{ Hormones } \\
\hline 57262 & Resistin-like $\alpha$ & 2.24 & 1.19 & 0.612 \\
\hline \multicolumn{5}{|l|}{ Immune function } \\
\hline 20311 & Chemokine (C-X-C motif) ligand 5 & 3.92 & 3.11 & 0.147 \\
\hline 12654 & Chitinase 3-like 1 & 3.34 & 8.43 & 0.359 \\
\hline \multicolumn{5}{|c|}{ Matrix molecules/cellular adhesion } \\
\hline 21922 & C-type lectin domain family 3 , member b & 2.38 & 0.27 & 0.141 \\
\hline \multicolumn{5}{|c|}{ Undefined function } \\
\hline 328660 & Brain expressed, $\mathrm{X}$-linked 6 & 2.48 & 1.54 & 0.218 \\
\hline 17141 & Melanoma antigen, family A, 5 & 2.47 & & 0.225 \\
\hline 68718 & Ring finger protein 166 & 2.25 & 0.64 & 0.390 \\
\hline 170654 & Keratin-associated protein $16-4$ & 2.04 & 1.08 & 0.389 \\
\hline \multicolumn{5}{|c|}{ Protease and protease inhibitors } \\
\hline 72432 & Serine protease inhibitor, Kazal type 5 (Spink5) & 4.36 & 3.46 & 0.140 \\
\hline 70574 & Carboxypeptidase M & 3.01 & 1.37 & 0.153 \\
\hline \multicolumn{5}{|c|}{ Cell surface receptors } \\
\hline 12638 & Cystic fibrosis transmembrane conductance regulator homolog & 2.61 & 0.84 & 0.151 \\
\hline 21942 & Tumor necrosis factor receptor superfamily, member 9 & 2.50 & 2.09 & 0.161 \\
\hline \multicolumn{5}{|c|}{ Signaling cascade } \\
\hline 76757 & Triadin & 2.63 & 0.16 & 0.081 \\
\hline 243659 & Serine/threonine/tyrosine kinase 1 & 2.51 & & 0.252 \\
\hline 14609 & Gap junction membrane channel protein $\alpha 1$ & 2.43 & 2.12 & 0.121 \\
\hline 100986 & A kinase (PRKA) anchor protein (yotiao) 9 & 2.27 & 3.12 & 0.215 \\
\hline 252837 & Chemokine (C-C motif) receptor-like 1 & 2.02 & 0.88 & 0.138 \\
\hline \multicolumn{5}{|c|}{ Transcription factors } \\
\hline 20861 & Stefin A1 & 3.00 & 1.62 & 0.242 \\
\hline 268885 & Stefin A2-like 1 & 2.83 & & 0.561 \\
\hline 268903 & Nuclear receptor interacting protein 1 & 2.44 & & 0.335 \\
\hline 19655 & RNA-binding motif protein, $\mathrm{X}$ chromosome & 2.13 & 0.75 & 0.065 \\
\hline 80913 & Pumilio 2 (Drosophila) & 2.06 & 1.45 & 0.506 \\
\hline 15220 & Forkhead box Q1 & 2.02 & 1.15 & 0.043 \\
\hline
\end{tabular}

*S.D. values are not shown for probe sets with only two expression values.

Though Cxcl5 expression varied throughout gestation, Cxcl5 was consistently expressed at higher levels during pregnancy than nonpregnancy (Fig. 5), but there was no specific pattern of expression with respect to duration of pregnancy (data not shown).

Purkinje cell protein 4 (Pcp4) was expressed in cervix, and similar to the microarray data, its expression declined on day 12 (Fig. 5). When the expression of this gene was evaluated throughout gestation and in the nonpregnant cervix, it was found to be highly expressed early in pregnancy and to gradually decline towards term (Fig. 6, upper panel). Given the potential role of this protein as an apoptosis inhibitor (Erhardt et al. 2000),
Pcp4 may play a role in suppression of apoptosis in the cervix during pregnancy. In the rat, apoptosis has been shown to be suppressed in the cervix during pregnancy and increases during parturition and post partum day 1 (Leppert \& Yu 1994, Ramos et al. 2002). Further experiments will determine if the gradual decline in expression of Pcp4 facilitates increased apoptosis of cervical cells during parturition and post partum repair.

Both Tff1 and Kazal-type serine peptidase inhibitor 5 (Spink5) were found to be expressed in cervix and upregulated on day 12 of pregnancy (Fig. 5). In addition, both genes were found to be highly upregulated with advancing gestation (Fig. 6, middle and lower panel). 
Table 3 Downregulated genes on day 12 when compared with day 10 of gestation in mouse cervical tissue.

\begin{tabular}{|c|c|c|c|c|}
\hline Entrez gene ID & Gene title & Fold change & S.D. ${ }^{*}$ & $P$ value \\
\hline \multicolumn{5}{|c|}{ Transport functions } \\
\hline 11576 & $\alpha$ fetoprotein & -7.63 & 5.98 & 0.348 \\
\hline 108052 & $\begin{array}{l}\text { Solute carrier family } 14 \text { (urea transporter), member } \\
1\end{array}$ & -2.07 & 0.69 & 0.013 \\
\hline \multicolumn{5}{|c|}{ Cytoskeletal components } \\
\hline 16561 & Kinesin family member 1B & -2.62 & & 0.518 \\
\hline 11459 & Actin, alpha 1 , skeletal muscle & -2.62 & 2.03 & 0.429 \\
\hline 245049 & Myosin VIIA and Rab-interacting protein & -2.41 & 1.54 & 0.229 \\
\hline 58187 & Claudin 10 & -2.36 & 1.59 & 0.295 \\
\hline \multicolumn{5}{|c|}{ DNA repair/RNA associated } \\
\hline 109113 & $\begin{array}{l}\text { Ubiquitin-like, containing PHD and RING finger } \\
\text { domains } 2\end{array}$ & -2.69 & 0.85 & 0.050 \\
\hline \multicolumn{5}{|c|}{ (1) } \\
\hline 17523 & Myeloperoxidase & -2.47 & & 0.354 \\
\hline 11687 & Arachidonate 15-lipoxygenase & -2.26 & 1.21 & 0.031 \\
\hline 11676 & Aldolase $3, \mathrm{C}$ isoform & -2.18 & 0.35 & 0.088 \\
\hline 77219 & $\begin{array}{l}\text { Zinc-binding alcohol dehydrogenase, domain } \\
\text { containing } 1\end{array}$ & -2.16 & 1.16 & 0.204 \\
\hline 16891 & Lipase, endothelial & -2.09 & 0.71 & 0.008 \\
\hline 20249 & Stearoyl-coenzyme A desaturase 1 & -2.08 & 0.59 & 0.036 \\
\hline 52815 & Lactate dehydrogenase D & -2.04 & 1.25 & 0.163 \\
\hline 12411 & Cystathionine beta-synthase & -2.01 & 0.79 & 0.056 \\
\hline \multicolumn{5}{|l|}{ Hormones } \\
\hline 18776 & Chorionic somatomammotropin hormone 2 & -3.51 & 2.43 & 0.338 \\
\hline \multicolumn{5}{|c|}{ Immune function } \\
\hline 76933 & Interferon, $\alpha$-inducible protein 27 & -2.13 & 1.03 & 0.213 \\
\hline \multicolumn{5}{|c|}{ Matrix molecules/cellular adhesion } \\
\hline 66996 & CEA-related cell adhesion molecule 11 & -8.72 & 9.18 & 0.355 \\
\hline \multicolumn{5}{|c|}{ Undefined function } \\
\hline 21984 & Trophoblast-specific protein $\alpha$ & -6.70 & 4.57 & 0.329 \\
\hline 327959 & F-box protein 39 & -2.28 & 1.42 & 0.444 \\
\hline 545422 & $\begin{array}{l}\text { Similar to low density lipoprotein receptor-related } \\
\text { protein } 2\end{array}$ & -2.22 & 1.39 & 0.142 \\
\hline \multicolumn{5}{|c|}{ Protease and protease inhibitors } \\
\hline 17230 & Mast cell protease 7 & -3.46 & 5.87 & 0.297 \\
\hline \multicolumn{5}{|c|}{ Cell surface receptors } \\
\hline 26563 & Receptor tyrosine kinase-like orphan receptor 1 & -2.15 & 1.43 & 0.113 \\
\hline 239849 & $\mathrm{Cd} 200$ receptor 4 & -2.00 & 0.72 & 0.407 \\
\hline \multicolumn{5}{|c|}{ Signaling cascade } \\
\hline 18546 & Purkinje cell protein 4 & -3.80 & 2.64 & 0.269 \\
\hline \multirow{2}{*}{\multicolumn{5}{|c|}{ Transcription factors }} \\
\hline & & & & \\
\hline 69188 & Myeloid/lymphoid or mixed-lineage leukemia 5 & -2.18 & & 0.916 \\
\hline 353187 & Nuclear receptor subfamily 1 , group D, member 2 & -2.08 & 1.28 & 0.202 \\
\hline 17877 & Myogenic factor 5 & -2.06 & & 0.923 \\
\hline
\end{tabular}

*s.D. values are not shown for probe sets with only two expression values.

Tff1 mRNA levels were low in cervical tissues from nonpregnant and pregnant animals on days 8 and 9 . During cervical softening, expression of Tff1 increased 2.8-fold from days 10 to 12 (from $2.6 \pm 0.6$ to $7.3 \pm 1.4$ relative units, $P=0.007$ ). Elevations in Tff1 during cervical softening was followed by a more dramatic increase in Tff1 mRNA prior to cervical ripening at term, such that Tff1 mRNA levels on late-gestation day 18 and after birth were over 1000-fold that in cervical tissues from nonpregnant or early pregnant animals (Fig. 6, middle panel).

Expression of Spink 5 was also regulated in the cervix during softening and ripening with a gestational age-dependent pattern of expression similar to Tff1. Cervical mRNA levels of Spink5 increased exponentially during cervical softening, throughout parturition and the post partum period. Expression of Spink5 during cervical softening was increased 2.1 -fold on day 12 versus day 10 $(0.7 \pm 0.02$ vs $0.15 \pm 0.04$ relative units, $P=0.05)$ (Fig. 4). Compared with early gestation (day 8), expression of Spink5 increased to greater than 650 -fold after birth (PP; Fig. 6, lower panel).

\section{Discussion}

\section{Molecular events regulating cervical softening are distinct from cervical ripening or dilation at term}

Studies outlined in this work suggest that the molecular processes of cervical softening differ significantly from ripening. Figure 7 illustrates some of these differences. Increases in tissue proliferation, hydration or distribution 


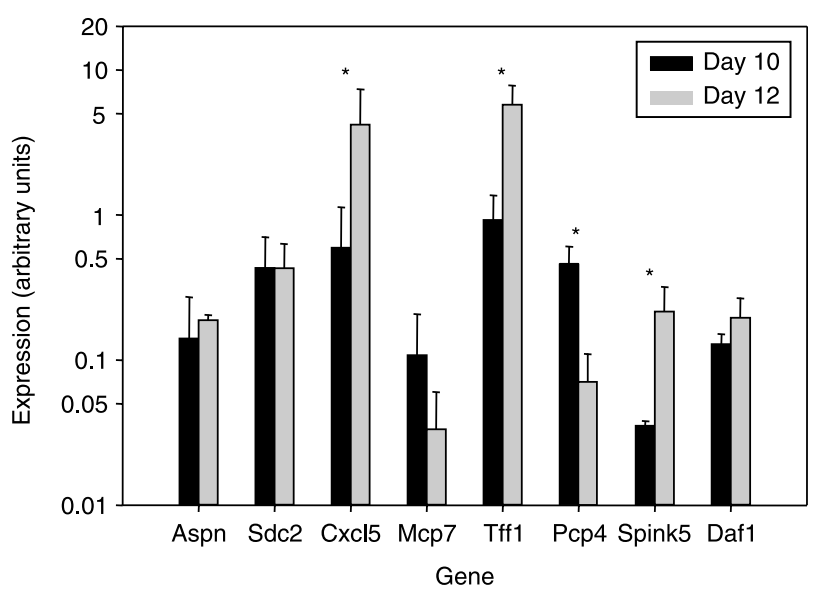

Figure 5 RT-PCR confirmation of differentially regulated genes identified in microarray comparisons between days 10 and 12 of gestation. Chemokine ligand 5 (CxCl5), Kazal-type serine protease inhibitor 5 (Spink5), and trefoil factor 1 (Tff1) were upregulated on day 12, while purkinje cell protein 4 (Pcp4) was downregulated on day 12. Significant changes in Asporin1 (Aspn), Syndecan 2 (Sdc2), mast cell protease (Mcp7), and decay-accelerating factor (Daf1) mRNA were not detected by QRT-PCR. Expression values are displayed in logarithmic scale and represent mean \pm s.E.M. of six cervices at each time point. ${ }^{*} P<0.05$ when compared with day 10 .

of inflammatory cells in cervical stromal matrix were not evident during cervical softening. Increases in collagen solubility appear to precede biomechanical evidence of softening, indicating that this is one of the earlier events in the remodeling process. Further studies are required to determine the steps in collagen synthesis, cross-linking and fibril assembly that may be altered in early pregnancy, thus explaining the observed changes in our collagen solubility data. Changes in solubility are not predicted to result from increased collagen degradation as the overall cervical collagen content did not decline significantly during softening or ripening and was actually increased after parturition (Fig. 3). Previous studies are inconsistent with our findings as they report small increases in collagen content in mouse cervices prior to parturition; however, no statistical analysis was carried out (Rimmer 1973). Similar to previous studies, collagen concentration was greatest early in pregnancy (day 7 ) and lowest during cervical ripening (day 18 ) and $10 \mathrm{~h}$ post partum (Rimmer 1973). This suggests that the processes leading to increased collagen solubility precede the molecular events that control cervical tissue compliance during cervical softening and ripening (Fig. 1).

An important question in the understanding of cervical remodeling is how the cervix can change its characteristics to promote softening throughout pregnancy yet remain closed to retain the developing fetus within the uterus. Biomechanical studies in the rat provide some insight into a dual mechanism that affects both cervical geometry and tissue stiffness. Cervical softening is influenced by the increase in cervical diameter with no change in cervical wall thickness and biomechanical
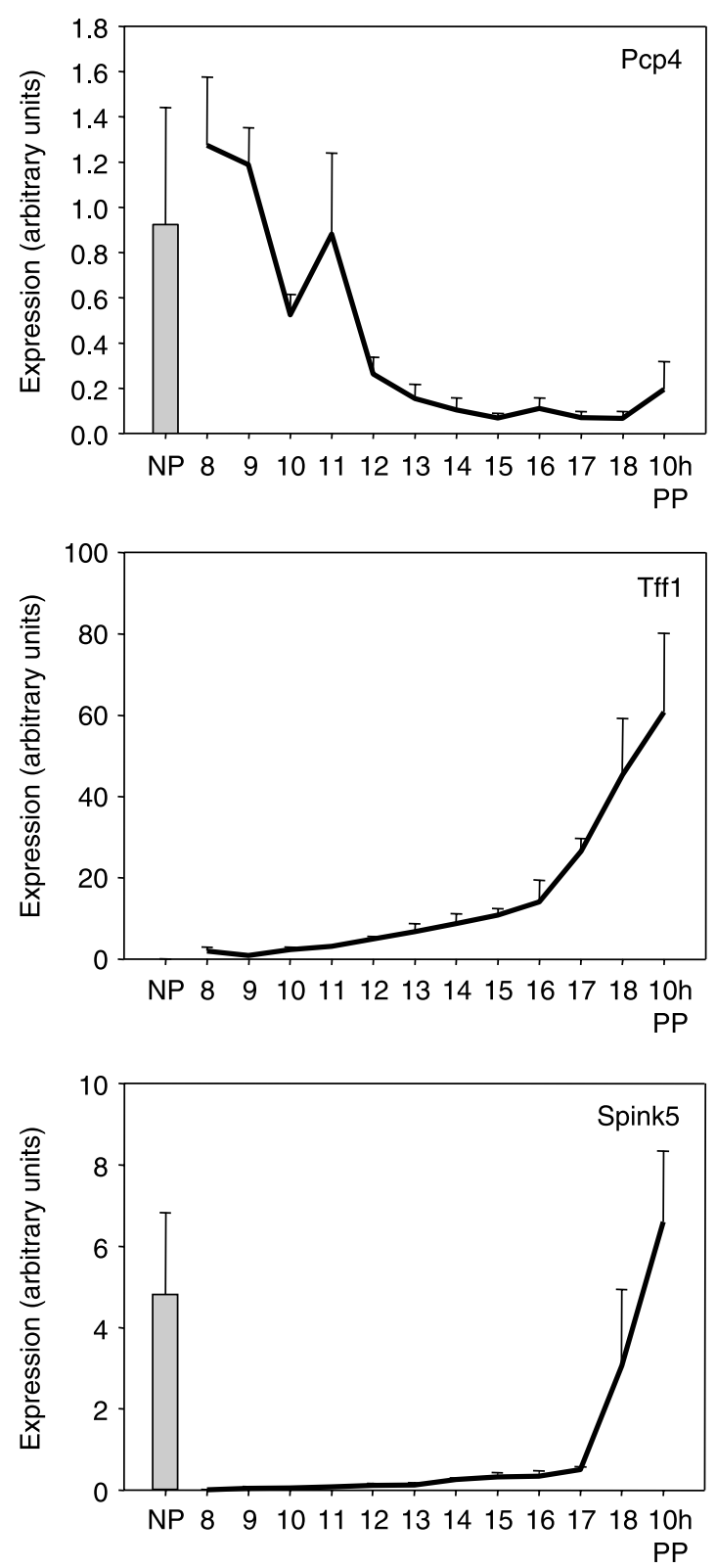

Figure 6 Expression of purkinje cell protein 4 (Pcp4, upper panel), Trefoil factor 1 ( $T f f 1$, middle panel), and Kazal-type serine protease inhibitor 5 (Spink5, lower panel) in cervical tissues from nonpregnant (NP) and pregnant mice. Cervices were obtained from nonpregnant (NP) and pregnant mice throughout gestation and the morning after parturition (10hPP). Expression of PCP4, Tff1, and Spink5 was quantified using RT-PCR and normalized to that of cyclophilin B (Ppib) as described in Materials and Methods. Data represent mean \pm s.E.M. of an average of three cervices per time point with the exception of days 10 and 12 in which data are estimated from nine cervices per time point. $P<0.001$ by ANOVA Kruskall-Wallis test day 8 through $10 \mathrm{hPP}$ for all three genes analyzed.

integrity of the cervix is maintained until late in gestation (Drzewiecki et al. 2005). Studies outlined in this study may provide insights into the biochemical changes that result in the dual biomechanical changes that promote softening. 


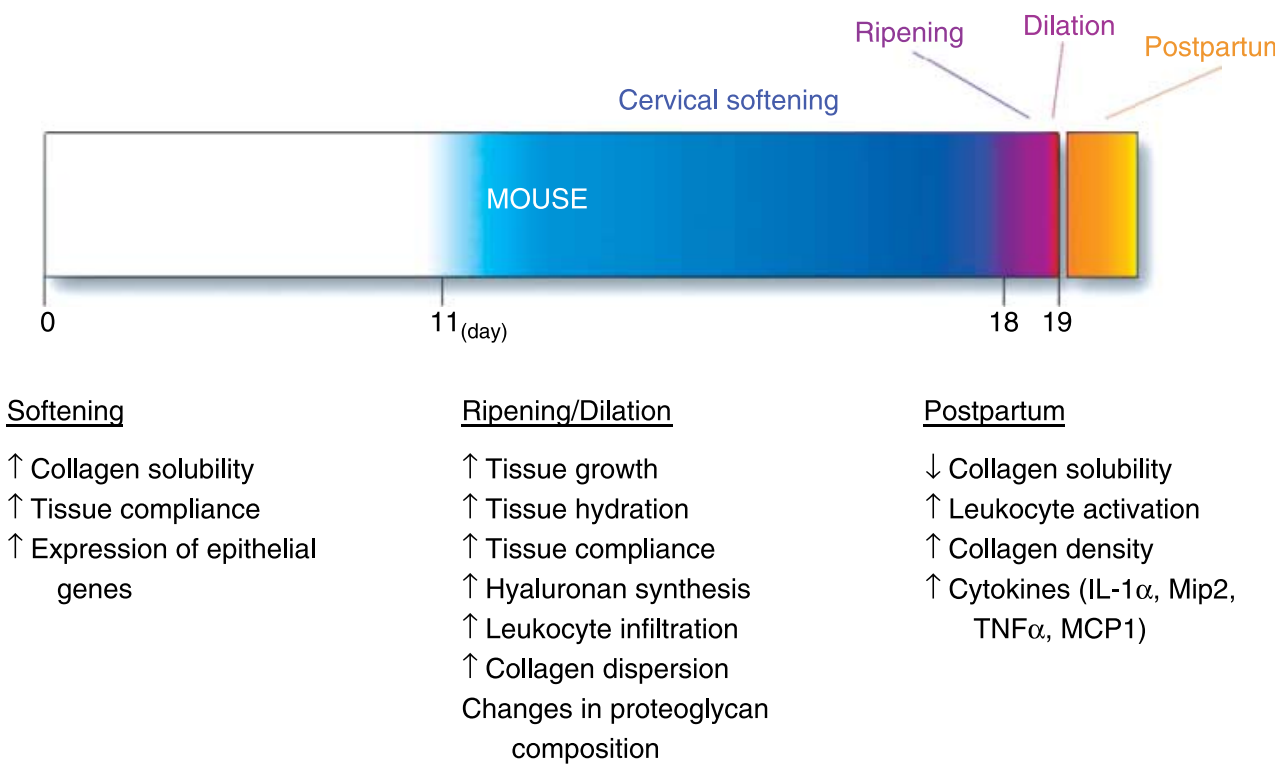

Figure 7 Representative schematic of the phases of mouse pregnancy. The changes in cervical physiology during mouse gestation can be divided into distinct yet overlapping phases: softening, ripening/dilation, and post partum repair. The ripening and dilation phases are described together as it is still not clear what processes may be distinct to these two phases. Processes described under post partum repair are those that occur in the immediate post partum period (within $24 \mathrm{~h}$ post partum).

In contrast to our observations with cervical softening, cervical ripening at the end of pregnancy is characterized by increased cell proliferation as well as reduced apoptosis of both the epithelia and the stroma which result in an increased circumference of the cervical lumen (Lee \& Sherwood 2005, Lee et al. 2005). Tissue water content is also increased presumably due to the increased expression of aquaporin water channel proteins (Anderson et al. 2006) and hydrophilic glycosaminoglycans (ElMaradny et al. 1997, Straach et al. 2005). Increases in the glycosaminoglycan, hyaluronan, result in disruption of the collagen matrix which, along with tissue growth, facilitates cervical ripening (ElMaradny et al. 1997, Straach et al. 2005). These differences between softening and ripening which are illustrated in Fig. 7, may explain why in the ripened cervix there is loss of structural integrity, tensile strength, as well as an increase in dilation in response to uterine contractions of labor, yet during softening, the cervix retains its structural integrity, tensile strength, and is resistant to forces exerted upon it.

\section{Distribution of inflammatory cells during cervical softening}

Inflammatory cells and cytokines are increased during cervical dilation of labor in all mammalian species studied (Bokstrom et al. 1997, Thomson et al. 1999, Sennstrom et al. 2000, Kelly 2002). The role of inflammatory cells in ripening before dilation; however, is not clear in women or mice (Sakamoto et al. 2004, Sakamoto et al. 2005, Timmons \& Mahendroo 2006).
In the mouse, cervical ripening (Phase 2) is characterized by a change in distribution of inflammatory cells with increased staining of monocytes and/or neutrophils within the cervical stroma (Timmons \& Mahendroo 2006). Studies conducted in cervical tissues from women and mice before and after cervical ripening (but before labor) failed to find significant increases in the number of granulocytes in the ripened cervix before labor (Sakamoto et al. 2004, 2005, Timmons \& Mahendroo 2006). Macrophage numbers are reported to increase in women and one study in mice during ripening but the antibodies used may also recognize tissue monocytes thus a functional role of these cells in ripening remains unclear (Mackler et al. 1999, Sakamoto et al. 2004).

In contrast to the later phases of cervical remodeling, midtrimester cervical softening phase was associated with little change in the distribution of macrophages or neutrophils. In addition, relatively few differentially expressed genes were identified that are involved with activation of the immune system by gene microarray comparisons. One exception was the expression of Cxcl5, a neutrophil chemoattractant made by epithelial cells (Walz et al. 1991, Imaizumi et al. 2003). Cxcl5 was expressed throughout gestation (data not shown) and is consistent with the fact that neutrophils are confined to the epithelial region at both gestation days 10 and 12 as well as later in pregnancy (Timmons \& Mahendroo 2006). We hypothesize that the localization of neutrophils in the epithelial region (Fig. 4, upper panel) helps to ensure that numerous surveillance mechanisms are in place during pregnancy to prevent ascending infections 
and protect the vulnerable, remodeling stromal matrix. Future studies to determine activation of inflammatory cells in a functional assay or measure cytokine levels directly will be required to verify that major inflammatory events do not mediate the softening process.

\section{Expression of epithelial-specific genes during cervical softening}

We initially hypothesized that changes in expression of genes affecting structure of collagen or elastin fibers would be identified in cervical tissues before and after cervical softening. This hypothesis is supported by i) decreased activity of the cross-linking enzyme, lysyl oxidase, in the mouse cervix during pregnancy, ii) changes in proteoglycan composition in the human and rat cervix during softening, and iii) the finding that mutations in the ECM proteins fibrillin-1 and thrombospondin 2 lead to premature cervical softening in women and mice respectively (Ozasa et al. 1981, Osmers et al. 1993, Kyriakides et al. 1998, Rahman et al. 2003, Kokenyesi et al. 2004). Contrary to our expectations, however, we were unable to detect significant changes in expression of ECM genes in the cervix from days 10 to 12. There are several possible explanations for these results. First, regulation of ECM proteins may occur at the post-transcriptional level that would not be reflected by changes in transcript expression using microarrays or RT-PCR. This possibility is suggested by studies that report no decrease in transcripts for small proteoglycans such as decorin, biglycan, and fibromodulin in the cervix from women at term despite a $50 \%$ reduction of total proteoglycan concentration (Westergren-Thorsson et al. 1998). Second, cervical epithelial cells undergo hyperplasia with advancing gestation such that the ratio of epithelial to stromal cells may change and therefore bias the microarray results towards epithelial-specific genes (Burger \& Sherwood 1998, Lee et al. 2005). Since, in these studies, whole cervix was used instead of fractionating the epithelial from the stromal compartment, the contribution of potentially important stromal genes may have been diluted. Finally, significant changes in mRNA levels of proteins affecting the ECM may have occurred prior to day 10 . Although changes in biophysical properties of the cervix were not detected until gestation day 12, significant changes in mRNA transcripts may have preceded cervical softening by several days. The fact that increases in collagen solubility (day 7 ) preceded changes in tissue compliance (day 12) further supports this idea. Studies are in progress to determine the biochemical and molecular changes that bring about increases in collagen solubility during early pregnancy.

Nevertheless, although genes encoding ECM molecules were not found to be differentially regulated during cervical softening, increased expression of several epithelial-specific genes were identified in the softened cervix on gestation day 12. The genes we identified are important in maintaining the integrity and barrier function of epithelia in the gut or skin. Tff1 and Spink5 are two genes that were significantly upregulated during cervical softening, and their expression progressively increased to peak at term and post partum. Based on their functions in gut and skin respectively, we propose that these transcripts encode proteins that may protect the cervix from infection and maintain the integrity and barrier function of the epithelia. Both of these genes are reported to be expressed in the female reproductive tract but have not been carefully explored with respect to female reproductive tract physiology (Wiede et al. 2001, Masui et al. 2006). The Tff1 gene encodes the estrogen-responsive protein, pS2, which is expressed in the gastric mucosa of humans and mice and involved in protection and restitution of mucosal epithelia (Shaoul et al. 2004, Hoffmann 2005). Tff1deficient mice $\left(\mathrm{Tff}^{-1-}\right.$ ) develop multiple antral gastric tumors from the loss of mucosal protection afforded by the pS2 protein (Lefebvre et al. 1996).

Spink5 is expressed in the differentiated layers of stratified epithelial tissue, and mutations in this gene have been shown to be the cause of autosomal-recessive Netherton syndrome (Netherton, 1958). Patients with this condition suffer from frequent bacterial infections. Spink $5^{-/}$mice die a few hours after birth from dehydration due to the lack of an intact permeability barrier of skin (Hewett et al. 2005). The gene product, lymphoepithelial Kazal-type related inhibitor, is a serine protease inhibitor that attenuates the functions of stratum corneum tryptic enzymes, which degrade desmoglein 1 as well as other proteins involved in barrier formation and maintenance (Descargues et al. 2005).

The transcriptional upregulation of Spink5 and Tff1 during cervical softening and continuing through parturition suggests that the cervical epithelia may play a greater role in the process of parturition than was previously recognized. Changes in stromal matrix must orchestrate, and are integral to, the change in biomechanical properties of the cervix. In addition, epithelial cells together with neutrophils lining the cervical os, may serve an immunomucosal protective role to prevent inappropriate access of invading microorganisms to the stromal matrix, which may be in a vulnerable, 'softened' state as well as prevent ascending infections into the upper reproductive tract. As the cervix loses structural integrity during ripening, parturition and post partum recovery of the cervix, the need for epithelial barrier protection potentially becomes even greater. Further studies on the role of Spink5 and Tff1 in cervical remodeling may enhance our understanding of molecular events that control parturition and determine if alterations in expression or function of these epithelial-specific genes could result in accelerated remodeling of the cervical ECM, thereby leading to the complications of cervical insufficiency and preterm birth. 


\section{Acknowledgements}

The authors wish to thank Jesús Acevedo and Joseph Davis for their excellent technical assistance. The authors declare that there is no conflict of interest that would prejudice the impartiality of this scientific work. This work is supported in part by NIH R01 HD043154 (M S Mahendroo) and P01HD111149 (R A Word).

\section{References}

Ananth CV, Joseph KS, Oyelese Y, Demissie K \& Vintzileos AM 2005 Trends in preterm birth and perinatal mortality among singletons: United States, 1989 through 2000. Obstetrics and Gynecology 105 1084-1091.

Anderson J, Brown N, Mahendroo MS \& Reese J 2006 Utilization of different aquaporin water channels in the mouse cervix during pregnancy and parturition and in models of preterm and delayed cervical ripening. Endocrinology 147 130-140.

Bokstrom H, Brannstrom M, Alexandersson M \& Norstrom A 1997 Leukocyte subpopulations in the human uterine cervical stroma at early and term pregnancy. Human Reproduction 12 586-590.

Branum AM \& Schoendorf KC 2002 Changing patterns of low birthweight and preterm birth in the United States, 1981-1998. Paediatric and Perinatal Epidemiology 16 8-15.

Buhimschi IA, Dussably L, Buhimschi CS, Ahmed A \& Weiner CP 2004 Physical and biomechanical characteristics of rat cervical ripening are not consistent with increased collagenase activity. American Journal of Obstetrics and Gynecology 191 1695-1704.

Burger LL \& Sherwood OD 1998 Relaxin increases the accumulation of new epithelial and stromal cells in the rat cervix during the second half of pregnancy. Endocrinology 139 3984-3995.

Danforth DN, Veis A, Breen M, Weinstein HG, Buckingham JC \& Manalo P 1974 The effect of pregnancy and labor on the human cervix: changes in collagen, glycoproteins, and glycosaminoglycans. American Journal of Obstetrics and Gynecology 120 641-651.

Descargues P, Deraison C, Bonnart C, Kreft M, Kishibe M, IshidaYamamoto A, Elias P, Barrandon Y, Zambruno G, Sonnenberg A et al. 2005 Spink5-deficient mice mimic Netherton syndrome through degradation of desmoglein 1 by epidermal protease hyperactivity. Nature Genetics 37 56-65.

Drzewiecki G, Tozzi C, Yu SY \& Leppert PC 2005 A dual mechanism of biomechanical change in rat cervix in gestation and postpartum: applied vascular mechanics. Cardiovascular Engineering V5 187-193.

EIMaradny E, Kanayama N, Kobayashi H, Hossain B, Khatun S, She LP, Kobayashi T \& Terao T 1997 The role of hyaluronic acid as a mediator and regulator of cervical ripening. Human Reproduction 12 1080-1088.

Erhardt JA, Legos JJ, Johanson RA, Slemmon JR \& Wang X 2000 Expression of PEP-19 inhibits apoptosis in PC12 cells. Neuroreport 11 3719-3723.

Funaba M, Ikeda T, Murakami M, Ogawa K, Nishino Y, Tsuchida K, Sugino H \& Abe M 2006 Transcriptional regulation of mouse mast cell protease-7 by TGF- $\beta$. Biochimica et Biophysica Acta 1759 166-170.

Granstrom L, Ekman G, Ulmsten U \& Malmstrom A 1989 Changes in the connective tissue of corpus and cervix uteri during ripening and labour in term pregnancy. British Journal of Obstetrics and Gynaecology 96 1198-1202.

Harkness ML \& Harkness RD 1959 Changes in the physical properties of the uterine cervix of the rat during pregnancy. Journal of Physiology 148 524-547.

Hegar AEL 1895 Diagnose der frühesten Schwangerschaftsperiode. Deutsche Medizinische Wochenschrift 21 565-567.
Henderson RB, Hobbs JA, Mathies M \& Hogg N 2003 Rapid recruitment of inflammatory monocytes is independent of neutrophil migration. Blood 102 328-335.

Hewett DR, Simons AL, Mangan NE, Jolin HE, Green SM, Fallon PG \& McKenzie AN 2005 Lethal, neonatal ichthyosis with increased proteolytic processing of filaggrin in a mouse model of Netherton syndrome. Human Molecular Genetics 14 335-346.

Hillier K \& Wallis RM 1982 Collagen solubility and tensile properties of the rat uterine cervix in late pregnancy: effects of arachidonic acid and prostaglandin F 2 a. Journal of Endocrinology 95 341-347.

Hoffmann W 2005 Trefoil factors TFF (trefoil factor family) peptidetriggered signals promoting mucosal restitution. Cellular and Molecular Life Sciences 62 2932-2938.

Horgan DJ, King NL, Kurth LB \& Kuypers R 1990 Collagen crosslinks and their relationship to the thermal properties of calf tendons. Archives of Biochemistry and Biophysics 281 21-26.

Imaizumi T, Kumagai $M$, Hatakeyama $M$, Tamo W, Yamashita $K$, Yoshida H, Munakata H \& Satoh K 2003 Effect of 15-deoxy- $\delta 12,14$ prostaglandin J2 on IL-1beta-induced expression of epithelial neutrophil-activating protein-78 in human endothelial cells. Prostaglandins Leukotrienes and Essential Fatty Acids 69 323-327.

Kanamori T, Takakura K, Mandai M, Kariya M, Fukuhara K, Kusakari T, Momma C, Shime H, Yagi H, Konishi M et al. 2003 PEP-19 overexpression in human uterine leiomyoma. Molecular Human Reproduction 9 709-717.

Kelly RW 2002 Inflammatory mediators and cervical ripening. Journal of Reproductive Immunology 57 217-224.

Kokenyesi R, Armstrong LC, Agah A, Artal R \& Bornstein P 2004 Thrombospondin 2 deficiency in pregnant mice results in premature softening of the uterine cervix. Biology of Reproduction 70 385-390.

Kyriakides TR, Zhu YH, Smith LT, Bain SD, Yang Z, Lin MT, Danielson KG, lozzo RV, LaMarca M, McKinney CE et al. 1998 Mice that lack thrombospondin 2 display connective tissue abnormalities that are associated with disordered collagen fibrillogenesis, an increased vascular density, and a bleeding diathesis. Journal of Cell Biology 140 419-430.

Lee HY \& Sherwood OD 2005 The effects of blocking the actions of estrogen and progesterone on the rates of proliferation and apoptosis of cervical epithelial and stromal cells during the second half of pregnancy in rats. Biology of Reproduction 73 790-797.

Lee HY, Zhao S, Fields PA \& Sherwood OD 2005 The extent to which relaxin promotes proliferation and inhibits apoptosis of cervical epithelial and stromal cells is greatest during late pregnancy in rats. Endocrinology 146 511-518.

Lefebvre O, Chenard MP, Masson R, Linares J, Dierich A, LeMeur M, Wendling C, Tomasetto C, Chambon P \& Rio MC 1996 Gastric mucosa abnormalities and tumorigenesis in mice lacking the pS2 trefoil protein. Science 274 259-262.

Leppert PC 1995 Anatomy and Physiology of Cervical Ripening. Clinical Obstetrics and Gynecology 38 267-279.

Leppert PC \& Yu SY 1994 Apoptosis in the cervix of pregnant rats in association with cervical softening. Gynecologic and Obstetric Investigation 37 150-154.

Leppi TJ 1964 A study of the uterine cervix of the mouse. Anatomical Record 150 51-65.

Liggins GC 1978 Ripening of the cervix. Seminars in Perinatology 2 261-271.

Lin F, Fukuoka Y, Spicer A, Ohta R, Okada N, Harris CL, Emancipator SN \& Medof ME 2001 Tissue distribution of products of the mouse decayaccelerating factor $(D A F)$ genes. Exploitation of a Daf1 knock-out mouse and site-specific monoclonal antibodies. Immunology 104 215-225.

Mackler AM, lezza G, Akin MR, McMillan P \& Yellon SM 1999 Macrophage trafficking in the uterus and cervix precedes parturition in the mouse. Biology of Reproduction 61 879-883.

Masui F, Kurosaki K, Mori T \& Matsuda M 2006 Persistent trefoil factor 1 expression imprinted on mouse vaginal epithelium by neonatal estrogenization. Cell and Tissue Research 323 167-175. 
Netherton EW 1958 A unique case of trichorrhexis nodosa; bamboo hairs. A. M. A. Archives of Dermatology 78 483-487.

Osmers R, Rath W, Pflanz MA, Kuhn W, Stuhlsatz HW \& Szeverenyi M 1993 Glycosaminoglycans in cervical connective tissue during pregnancy and parturition. Obstetrics and Gynecology 81 88-92.

Ozasa H, Tominaga T, Nishimura T \& Takeda T 1981 Lysyl oxidase activity in the mouse uterine cervix is physiologically regulated by estrogen. Endocrinology 109 618-621.

Papiernik E, Bouyer J, Collin D, Winisdoerffer G \& Dreyfus J 1986 Precocious cervical ripening and preterm labor. Obstetrics and Gynecology 67 238-242.

Paternoster DM, Santarossa C, Vettore N, Dalla Pria S \& Grella P 1998 Obstetric complications in Marfan's syndrome pregnancy. Minerva Ginecologica 50 441-443.

Rahman J, Rahman FZ, Rahman W, al-Suleiman SA \& Rahman MS 2003 Obstetric and gynecologic complications in women with Marfan syndrome. Journal of Reproductive Medicine 48 723-728.

Ramos JG, Varayoud J, Bosquiazzo VL, Luque EH \& Munoz-de-Toro M 2002 Cellular turnover in the rat uterine cervix and its relationship to estrogen and progesterone receptor dynamics. Biology of Reproduction 67 735-742.

Reiner A, Yekutieli D \& Benjamini Y 2003 Identifying differentially expressed genes using false discovery rate controlling procedures. Bioinformatics 19 368-375.

Rimmer DM 1973 The effect of pregnancy on the collagen of the uterine cervix of the mouse. Journal of Endocrinology 57 413-418.

Robins SP, Milne G, Duncan A, Davies C, Butt R, Greiling D \& James IT 2003 Increased skin collagen extractability and proportions of collagen type III are not normalized after 6 months healing of human excisional wounds. Journal of Investigative Dermatology 121 267-272.

Sakamoto Y, Moran P, Searle RF, Bulmer JN \& Robson SC 2004 Interleukin-8 is involved in cervical dilatation but not in prelabour cervical ripening. Clinical and Experimental Immunology 138 151-157.

Sakamoto Y, Moran P, Bulmer JN, Searle RF \& Robson SC 2005 Macrophages and not granulocytes are involved in cervical ripening. Journal of Reproductive Immunology 66 161-173.

Sennstrom MB, Ekman G, Westergren-Thorsson G, Malmstrom A, Bystrom B, Endresen U, Mlambo N, Norman M, Stabi B \& Brauner A 2000 Human cervical ripening, an inflammatory process mediated by cytokines. Molecular Human Reproduction 6 375-381.

Shaoul R, Okada Y, Cutz E \& Marcon MA 2004 Colonic expression of MUC2, MUC5AC, and TFF1 in inflammatory bowel disease in children. Journal of Pediatric Gastroenterology and Nutrition 38 488-493.

Singh UP, Singh S, Boyaka PN, McGhee JR \& Lillard JW Jr 2004 Granulocyte chemotactic protein-2 mediates adaptive immunity in part through IL-8R $\beta$ interactions. Journal of Leukocyte Biology 76 1240-1247.

Stegemann H \& Stalder K 1967 Determination of hydroxyproline. Clinica Chimica Acta 18 267-273.
Straach KJ, Shelton JM, Richardson JA, Hascall VC \& Mahendroo MS 2005 Regulation of hyaluronan expression during cervical ripening. Glycobiology 15 55-65.

Taylor PR, Brown GD, Geldhof AB, Martinez-Pomares L \& Gordon S 2003 Pattern recognition receptors and differentiation antigens define murine myeloid cell heterogeneity ex vivo. European Journal of Immunology 33 2090-2097.

Thomson AJ, Telfer JF, Young A, Campbell S, Stewart CJ, Cameron IT, Greer IA \& Norman JE 1999 Leukocytes infiltrate the myometrium during human parturition: further evidence that labour is an inflammatory process. Human Reproduction 14 229-236.

Timmons BC \& Mahendroo MS 2006 Timing of neutrophil activation and expression of proinflammatory markers do not support a role for neutrophils in cervical ripening in the mouse. Biology of Reproduction 74 236-245.

Uldbjerg N, Ekman G, Malmstrom A, Olsson K \& Ulmsten U 1983 Ripening of the human uterine cervix related to changes in collagen, glycosaminoglycans, and collagenolytic activity. American Journal of Obstetrics and Gynecology 147 662-666.

Walz A, Burgener R, Car B, Baggiolini M, Kunkel SL \& Strieter RM 1991 Structure and neutrophil-activating properties of a novel inflammatory peptide (ENA-78) with homology to interleukin 8. Journal of Experimental Medicine 174 1355-1362.

Welle S, Brooks AI \& Thornton CA 2002 Computational method for reducing variance with affymetrix microarrays. BMC Bioinformatics 323.

Westergren-Thorsson $G$, Norman $M$, Bjornsson S, Endresen $U$, Stjernholm Y, Ekman G \& Malmstrom A 1998 Differential expressions of mRNA for proteoglycans, collagens and transforming growth factor- $\beta$ in the human cervix during pregnancy and involution. Biochimica et Biophysica Acta 1406 203-213.

Wiede A, Hinz M, Canzler E, Franke K, Quednow C \& Hoffmann W 2001 Synthesis and localization of the mucin-associated TFFpeptides in the human uterus. Cell and Tissue Research 303 109-115.

Word RA, Landrum CP, Timmons BC, Young SG \& Mahendroo MS 2005 Transgene insertion on mouse chromosome 6 impairs function of the uterine cervix and causes failure of parturition. Biology of Reproduction 73 1046-1056.

Word RA, Li XH, Hnat M \& Carrick K 2007 Dynamics of cervical remodeling during pregnancy and parturition: mechanisms and current concepts. Seminars in Reproductive Medicine 25 69-79.

Yang T, Liang DC, Koch PJ, Hohl D, Kheradmand F \& Overbeek PA 2004 Epidermal detachment, desmosomal dissociation, and destabilization of corneodesmosin in Spink5(-/-) mice. Genes and Development 18 2354-2358.

Received 18 January 2007

First decision 26 February 2007

Revised manuscript received 18 April 2007

Accepted 27 April 2007 